\title{
Role of irbesartan in protection against pulmonary toxicity induced by bleomycin in rats
}

\author{
Mariam A. El-Gamal ${ }^{1}$, Sawsan A. Zaitone ${ }^{2}$, and Yasser M. Moustafa ${ }^{2}$ \\ ${ }^{I}$ (Directorate of health and population, Port Said, Egypt) \\ ${ }_{2}^{2}$ (Department of Pharmacology \& Toxicology, Faculty of Pharmacy, Suez Canal University, Ismailia 41522, \\ Egypt)
}

\begin{abstract}
Bleomycin (BLM) is an anti-neoplastic, antibiotic drug that produces dose and time dependant pulmonary fibrosis. Recent studies reported some mechanisms of irbesartan in attenuating lung and skin fibrosis in mice. Therefore, the current study was conducted to examine the effect of irbesartan focusing on angiogenesis and plasminogen activator inhibitor-1(PAI-1) expression as possible mechanisms in protection against BLM-induced lung fibrosis in rats. The effect of irbesartan on the serum and tissue levels of growth factors and mRNA expression of PAI-1 were studied. Oral administration of irbesartan $(10,20$ and 40 $\mathrm{mg} / \mathrm{kg} /$ day) to rats for 21 days, starting from the first day of bleomycin injection $(10 \mathrm{mg} / \mathrm{kg} /$ day $/ 10$ days, i.p. $)$ attenuated the severity of BLM-induced pulmonary fibrosis, enhanced the histopathological features of the lungs, reduced serum transforming growth factor- $\beta_{1}\left(T G F-\beta_{1}\right)$ compared to BLM group without any improvement in the survival percentage. In addition, immunohistochemical staining revealed lower expression of angiotensin-II type 1 receptor $\left(A T_{1}\right)$ and $\alpha$-smooth muscle actin $(\alpha-S M A)$ in lung tissues after treatment with irbesartan (20 and 40mg/kg) compared to BLM-treated group. Importantly, irbesartan (10, 20 and $40 \mathrm{mg} / \mathrm{kg}$ ) suppressed the expression of PAI-1 gene in lung tissues while increased both serum level and immunohistochemical staining of vascular endothelial growth factor (VEGF) compared to BLM-treated group. So that, the present study concluded that the ameliorating effect of irbesartan against BLM-induced pulmonary fibrosis in rats involves increasing angiogenesis, reduction of PAI-1 gene expression and modulation of growth factors.
\end{abstract}

Keywords - Angiogenesis, bleomycin, irbesartan, plasminogen activator inhibitor-1, pulmonary fibrosis.

\section{INTRODUCTION}

Pulmonary fibrosis is a chronic end stage of interstitial lung diseases which progress to complete loss of lung function and death in affected patients [1]. Pulmonary fibrosis characterized by the histological pattern of usual interstitial pneumonia [2] with excessive accumulation of extracellular matrix (ECM), fibroblast proliferation and remodeling of the lung architecture. In the current study, pulmonary fibrosis was induced in rats by i.p injection of bleomycin, an antibiotic drug with anti-neoplastic activity which was originally isolated from the fungus Streptomyces verticillus [3].The bleomycin induces pulmonary fibrosis which produces pathological events similar to those found in human fibrotic lung disease [4].

Angiotensin-II is the main peptide of renin-angiotensin system that regulates cell growth, vessel growth, inflammation and fibrosis via acting through $\mathrm{AT}_{1}$ receptors [5]. Some of the angiotensin-II effects have been linked to the induction of cytokines like TNF- $\alpha$, a pro-inflammatory factor which activates other inflammatory cytokines, and growth factors expression as TGF- $\beta_{1}[6]$, a major pro-fibrogenic mediator increases the production and secretion of collagen and induces production and differentiation of lung fibroblasts in vitro, and VEGF [7], pro-angiogenic factor which is involved in endothelial cell proliferation, inflammation and angiogenesis, the formation of new vessels from preexisting blood vessels. As angiogenesis plays a critical role in pathologic and physiologic responses and can improve the severity of various diseases.

Angiotensin-II is also involved in activating PAI-1 [8]. PAI-1 is a member of the serine protease inhibitor family, and is the major physiological inhibitor of both tissue and urokinase plasminogen activators [9]. PAI-1 reduces the conversion of plasminogen to plasmin, an extracellular protease that mediates fibrinolysis [10] and results in ECM deposition and fibrosis.

Irbesartan is a potent selective $\mathrm{AT}_{1}$ receptor antagonist that shows high affinity to $\mathrm{AT}_{1}$ receptors and serves as an anti-hypertensive drug [11]. Recent studies reported the ameliorating effect of irbesartan on fibrotic lung [12] and skin [13] in mice. So that, this study was conducted to evaluate the protective role of 
irbesartan in rats against lung fibrosis induced by bleomycin focusing on its effect on angiogenesis and PAI-1 as possible mechanisms could be involved in lung fibrosis induced by bleomycin in rats.

\subsection{Animals}

\section{MATERIALS AND METHODS}

Sixty male albino rats weighing about 200-250 g were supplied by the Egyptian Organization for Biological Products and Vaccines (Vacsera, Egypt). Rats were housed in groups of six, 10 animals each and maintained under standard conditions (normal light/dark cycle, temperature $25 \pm 3{ }^{\circ} \mathrm{C}$ and $55 \%$ relative humidity) with free access to water and rodent laboratory food. Rats were acclimatized to the new environment for 1 week prior to the experiment. All the experimental protocols were approved by the Animal Care and Use Committee at the Faculty of Pharmacy, Suez Canal University.

\subsection{Drugs and chemicals}

Bleomycin hydrochloride (Nippon Kayaku, Tokyo, Japan) was freshly prepared in phosphate buffered saline solution (PBS, $\mathrm{pH}=7.4$ ). Irbesartan powder was kindly provided by Medical Union Pharmaceutical Co. (Ismailia, Egypt). 3', 3'-diaminobenzidine (DAB) was purchased from Sigma-Aldrich ${ }^{\circledR}$ (MO, USA). All other chemicals used in the present study were of analytical grade and obtained from Adwic Co. (Cairo, Egypt).

\subsection{Experimental design}

Rats were randomly allocated into six groups: Group I: rats were injected with PBS (Vehicle of BLM) in a volume of ( $3 \mathrm{ml} / \mathrm{kg} / \mathrm{day} / 10$ days, i.p.) parallel to BLM injection.

Group II: rats were injected with BLM $(10 \mathrm{mg} / \mathrm{kg} / \mathrm{day} / 10$ days, i.p.) to induce lung fibrosis. Group III, IV and $\mathrm{V}$ : rats were injected with BLM $(10 \mathrm{mg} / \mathrm{kg} / \mathrm{day} / 10$ days, i.p.) in addition to oral irbesartan-starting from the first day of BLM injection- at doses of $(10,20$ and $40 \mathrm{mg} / \mathrm{kg} /$ day/21 days) in volumes of $(1,2$ and $3 \mathrm{ml} / \mathrm{kg})$, respectively. Group VI: healthy rats were injected with PBS (vehicle of BLM, $3 \mathrm{ml} / \mathrm{kg} / \mathrm{day} / 10$ days, i.p.) in addition to oral irbesartan $(40 \mathrm{mg} / \mathrm{kg} /$ day $/ 21$ days) in a volume of $(3 \mathrm{ml} / \mathrm{kg})$. This group was performed to explore any toxic effect of irbesartan on the lung. The experiment continued up to 21 days. In general, BLM was freshly prepared in PBS and the concentration was adjusted so that, each rat received $3 \mathrm{ml} / \mathrm{kg}$ body weight. Irbesartan powder was freshly prepared in $2 \% \mathrm{CMC}$ solution and given by gastric gavages. The animals were weighed at the beginning, through, and at the end of experiments.

\subsection{Blood collection, lung coefficient and tissue samples}

At the end of the study protocol, a $2 \mathrm{ml}$ blood sample was obtained under anesthesia from the orbital sinus. Thirty min after collection, blood samples were processed by centrifugation at $2000 \times \mathrm{g}$ for $15 \mathrm{~min}$. Then, serum samples were separated and stored at $-80^{\circ} \mathrm{C}$ for different assays.

Rats were sacrificed and the lungs were excised, rinsed with ice-cold PBS and weighed to calculate the ratio of lung weight to body weight as lung coefficient [14]. These ratios indicated lung inflammation and fibrosis. Then, the lungs were divided; the right lung was kept at $-80^{\circ} \mathrm{C}$ whereas, the left lung was fixed using $10 \%$ phosphate-buffered paraformaldehyde solution $(\mathrm{pH}=7.4)$ for $18 \mathrm{~h}$ and then embedded in paraffin. After that, all tissues were sectioned at $4 \mu \mathrm{m}$ thicknesses and left to dry over night at $37^{\circ} \mathrm{C}$. Sections were then subjected to deparaffinized, rehydration and prepared for histological or immunohistochemical staining for $\mathrm{AT}_{1}, \alpha-\mathrm{SMA}$ and VEGF.

\subsection{Measurement of serum TNF- $\alpha$, TGF- $\beta_{1}$ and VEGF levels using ELISA kits}

Enzyme-linked immunosorbent assay kits for detection of serum TNF- $\alpha$ and VEGF levels (Ray Biotech Inc ${ }^{\circledR}$, Norcross, USA) and for serum TGF- $\beta_{1}$ level (Boster Biological technology ${ }^{\circledR}$, Wuhan, China), were carried out following the instructions of manufacturer using an automated ELISA reader (Europe S.A., Belgium).

\subsection{Histopathological examination of the lung tissues}

Tissues stained with Masson's trichrome stain (Sigma-Aldrich Co., MO, USA) to assess the degree of fibrosis. For the quantitative histological analysis, a numerical fibrotic scale was used "Ashcroft score" [15]. Briefly, two pathologists scored the grade of lung fibrosis in blinded fashion on a scale of 0-8 by examining six randomly chosen fields per sample. The scoring was performed at high power ( $\times 40$ magnification). The criteria for grading lung fibrosis were as follows: grade (0): normal lung; grade (1): minimal fibrous thickening of alveolar or bronchiolar walls; grade (2-3): moderate thickening of walls without obvious damage to lung 
architecture; grade (4-5): increased fibrosis with definite damage to lung structure and formation of fibrous bands or small fibrous masses; grade (6-7): severe distortion of structure and large fibrous areas; and grade (8): total fibrous obliteration of fields. The mean score of all fields was taken as the fibrosis score of that lung section.

\subsection{Immunohistochemical staining and image analysis}

Immunostaining was performed using streptavidin-biotin-immunoperoxidase complex method with 4 $\mu \mathrm{m}$ thick sections, which had been deparaffinized, hydrated and heated in $0.01 \mathrm{M}$ citrate buffer solution $(\mathrm{pH}=$ 6.0) for antigen retrieval. Sections were incubated with corresponding primary antibody, mouse monoclonal antibodies against $\mathrm{AT}_{1}$ receptors $\left(\mathrm{Abcam}^{\circledR}\right.$, Cambridge, CB40FL, UK) and mouse monoclonal antibodies against $\alpha$-SMA and VEGF (Labvision ${ }^{\circledR}$, Fremont, CA 94538, USA) at $4^{\circ} \mathrm{C}$ overnight. After conjugation with streptavidin-biotin-peroxidase complex, coloring was performed with DAB as chromogen and Mayer's hematoxylin was used as counter stain. Slides were examined blindly by an experienced pathologist using a light microscope (Olympus CX21, Japan). Photomicrographs captured at $\mathrm{x} 100$ magnification. Immunoreactivity for $\mathrm{AT}_{1}, \alpha$-SMA and VEGF was evaluated with reference to the optical density of the stain using an image analysis system "Image J 1.45F" (National Institute of Health, USA). The optical density was determined on ten consecutive sections representative to the whole tissue section.

\subsection{Quantitative reverse transcription-polymerase chain reaction}

Total RNA was extracted from frozen lung tissue samples (100 mg) using an RNA extraction kit (Qiagen, Hilden, Germany) and treated with DNase to remove any residual genomic DNA. The concentration of the RNA extracted was measured using a NanoDrop ND-1000 (Thermo Fisher Scientific, Wilmington, DE, USA). Single-stranded cDNA was synthesized from 5 to $10 \mu \mathrm{g}$ total RNA using Superscript II Reverse Transcriptase (Gibco BRL; Life Technologies, Bethesda, MD, USA). To determine PAI-1 in lung tissue, the following specific primers were used: rat PAI-1 cDNA fragment, 5'-AGCTGGGCATGACTGACATCT-3' (primer 1) and 5'-GCTGCTCTTGGTCGGAAAGA-3' (primer 2); and $\beta$-actin, 5'TTCAACACCCCAGCCATGT-3' (sense) and 5'-AGTGGTACGACCAGAGGCATACA-3' (antisense) [16]. All primers were used at a final concentration of $0.5 \mu \mathrm{mol} / \mathrm{L}$. Quantification of transcripts was performed with the Light Cycler 480 Real-Time PCR System (Roche Diagnostics, Mannheim, Germany) and target sequences were detected using the Universal Probe Library (UPL; Roche Diagnostics GmbH, Roche Applied Science, Mannheim, Germany). Data were analyzed with LIGHT CYCLER 480 Software. The detection format was set to 'Mono Color Hydrolysis Probe' and the second derivative maximum method was used for absolute quantification.

\subsection{Statistical analysis}

All results were expressed as mean \pm S.E.M. Results were assessed using one-way analysis of variance, ANOVA, followed by Bonferroni's test for multiple comparisons. Data were analyzed employing The Statistical Package for the Social Sciences, version 17 (SPSS Software, SPSS Inc., Chicago, USA). A value of $\mathrm{P}<0.05$ was considered to be statistically significant.

\section{Results}

3.1. Effect of irbesartan on percentage survival, body weight, lung weight and lung coefficient In the present study, pulmonary fibrosis was induced in rats by injection of BLM $(10 \mathrm{mg} / \mathrm{kg}$, i.p. $)$ for 10 days. BLM injection resulted in a decrease in the percentage of surviving rats (70\%) compared to a surviving percentage equals (100\%) in vehicle-treated rats. Further BLM-treated rats showed a decrease in the total body weight and an increase in the lung coefficient compared to the vehicle group $(\mathrm{P}<0.05$, Table 1). Treatment with irbesartan $(10,20$ and $40 \mathrm{mg} / \mathrm{kg}$ ) for 21 days -starting from first day of bleomycin injection- did not significantly improve the survival of rats compared to BLM group (Table 1). However, irbesartan $(40 \mathrm{mg} / \mathrm{kg})$ reduced weight loss and decreased the lung coefficient of the survived rats compared to BLM- and irbesartan $(10 \mathrm{mg} / \mathrm{kg})$ groups $(\mathrm{P}<0.05$, Table 1). Treatment of healthy rats with irbesartan $(40 \mathrm{mg} / \mathrm{kg})$-for the same period of time- did not induce any mortality and showed an increase in the mean final body weight and a decrease in the lung coefficient compared to BLM group $(\mathrm{P}<0.05$, Table 1$)$. 
Table 1: Effect of Irbesartan (10, 20 and 40mg/kg/day/21day) on survival percentage, body weight, lung weight and lung coefficient in BLM-induced lung fibrosis in rats. BLM: bleomycin, Irb: irbesartan, BWt: body weight, LWt: lung weight. Values are expressed as mean \pm S.E.M and analyzed using one-way ANOVA followed by Bonferroni's multiple comparisons test, $\mathrm{n}=10 .{ }^{\mathrm{a}} \mathrm{P}<0.05$ compared to vehicle group, ${ }^{\mathrm{b}} \mathrm{P}<0.05$ compared to BLM group, ${ }^{\mathrm{c}} \mathrm{P}<0.05$ compared to irbesartan $(10 \mathrm{mg} / \mathrm{kg})$ group.

\begin{tabular}{|c|c|c|c|c|c|}
\hline Groups & $\begin{array}{c}\text { Survival } \\
\text { (percentage) } \\
\%\end{array}$ & $\begin{array}{l}\text { Baseline } \\
\text { BWt (g) }\end{array}$ & $\begin{array}{c}\text { Final } \\
\text { BWt }(g)\end{array}$ & $\begin{array}{c}\text { Lung } \\
\text { Wt (g) }\end{array}$ & $\begin{array}{l}\text { Lung Co-efficient } \\
\text { LWt (mg)/BWt (g) }\end{array}$ \\
\hline Vehicle & 100 & $204.5 \pm 5.16$ & $226.4 \pm 9.58$ & $1.69 \pm 0.09$ & $7.46 \pm 0.2$ \\
\hline BLM & $70^{\mathrm{a}}$ & $208.42 \pm 5.22$ & $191.25 \pm 9.11^{\mathrm{a}}$ & $1.7 \pm 0.07$ & $8.99 \pm 0.36^{\mathrm{a}}$ \\
\hline BLM+ Irb (10mg/kg) & 60 & $208 \pm 1.93$ & $192.17 \pm 2.36$ & $1.70 \pm 0.05$ & $8.84 \pm 0.22$ \\
\hline BLM+ Irb $(20 \mathrm{mg} / \mathrm{kg})$ & 50 & $210.3 \pm 2.67$ & $197.8 \pm 4.07$ & $1.66 \pm 0.01$ & $8.41 \pm 0.13$ \\
\hline BLM+ Irb (40mg/kg) & 50 & $214.9 \pm 2.21$ & $204.75 \pm 2.71^{\mathrm{bc}}$ & $1.68 \pm 0.09$ & $8.27 \pm 0.44^{\mathrm{bc}}$ \\
\hline $\operatorname{Irb}(40 \mathrm{mg} / \mathrm{kg})$ & 100 & $219.5 \pm 2.4$ & $243.5 \pm 10.65^{\mathrm{b}}$ & $1.8 \pm 0.11$ & $7.41 \pm 0.34^{b}$ \\
\hline
\end{tabular}

\subsection{Effect of irbesartan on serum TNF- $\alpha$, TGF- $\beta_{1}$ and VEGF levels}

Serum TNF- $\alpha$ level did not differ significantly among all the study groups (Fig. 1A). Injection with BLM (10 mg/kg, i.p.) increased serum TGF- $\beta_{1}$ and VEGF levels compared to vehicle- treated rats $(\mathrm{P}<0.05$, Fig. 1B\& C). Treatment with irbesartan $(10,20$ and $40 \mathrm{mg} / \mathrm{kg})$ decreased TGF- $\beta_{1}$ and increased VEGF levels compared to BLM group (P < 0.05, Fig. 1B\& C). Further, irbesartan $(40 \mathrm{mg} / \mathrm{kg})$ showed a decrease in TGF- $\beta_{1}$ level in the survived rats compared to irbesartan $(10 \mathrm{mg} / \mathrm{kg}, \mathrm{P}<0.05)$. Treatment of healthy rats with irbesartan $(40 \mathrm{mg} / \mathrm{kg})$ showed a comparable serum VEGF levels with higher serum TGF- $\beta_{1}$ compared to vehicle-treated group but showed lower serum levels of TGF- $\beta_{1}$ and VEGF compared to BLM group $(\mathrm{P}<0.05$, Fig. 1B\& $\mathrm{C})$.
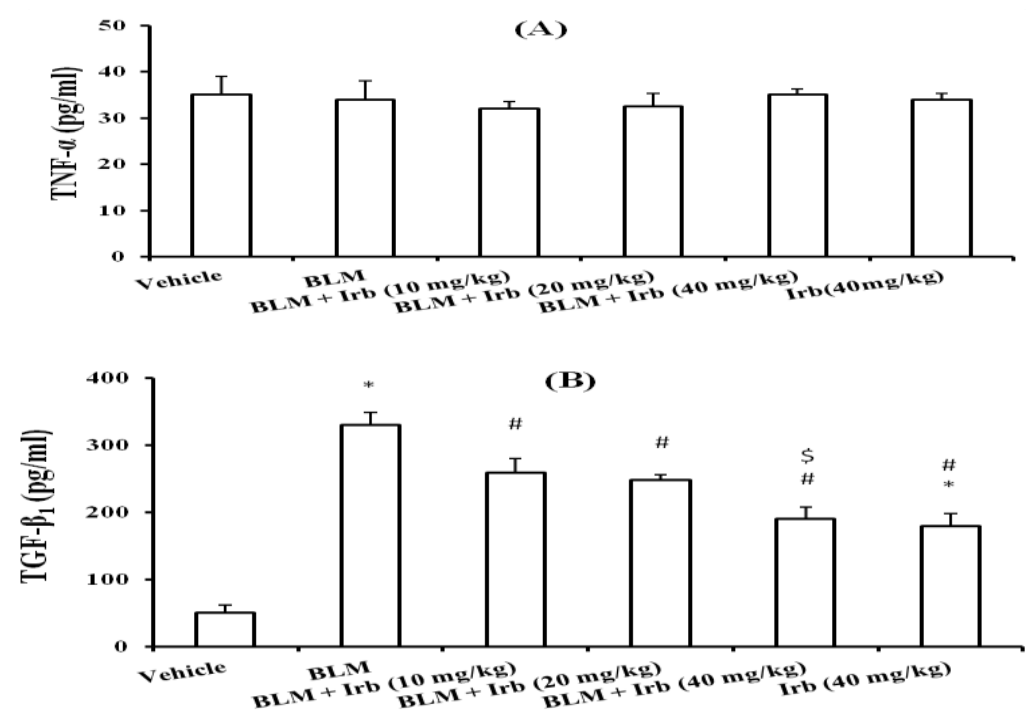


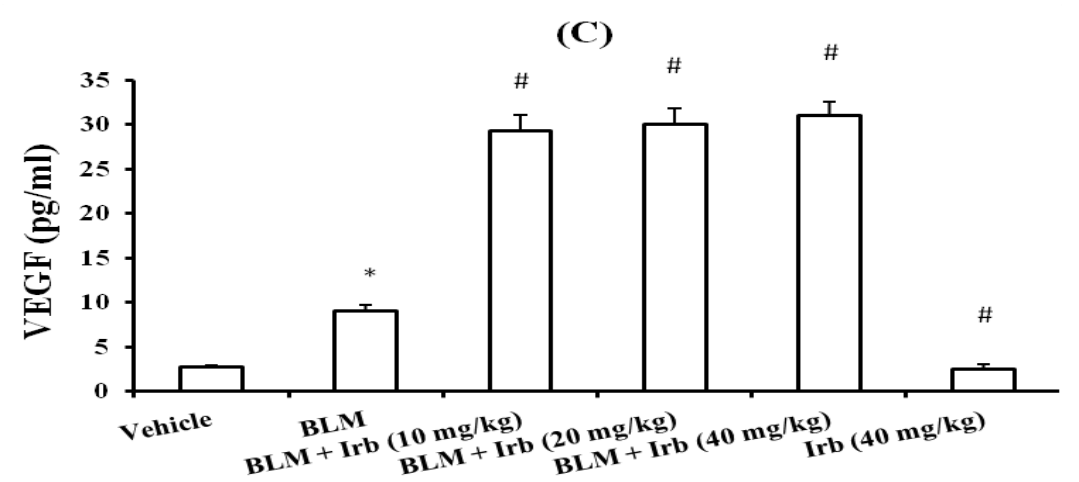

Figure 1: Effect of Irbesartan $\left(10,20\right.$ and $40 \mathrm{mg} / \mathrm{kg}$ ) on serum level of TNF- $\alpha$ (A), TGF- $\beta_{1}$ (B) and VEGF (C) in BLM-induced lung fibrosis in rats. BLM: bleomycin, Irb: irbesartan. Values are expressed as mean \pm S.E.M. and analyzed using one-way ANOVA followed by Bonferroni's multiple comparisons test. " Compared to vehicle group at $\mathrm{P}<0.05,{ }^{\#}$ Compared to BLM group at $\mathrm{P}<0.05,{ }^{\$}$ Compared to irbesartan $(10 \mathrm{mg} / \mathrm{kg})$ group at $\mathrm{P}<0.05, \mathrm{n}=10$.

\subsection{Effect of irbesartan on BLM-induced histopathological changes}

The histological examination of the lung tissues revealed that vehicle-treated group showed normal alveolar, bronchial walls and normal lung architecture with mean fibrosis score of (0, Fig. 2, A\& B). However, lung tissues in BLM group exhibited a marked thickening of alveolar walls, pulmonary inflammation and leukocytes infiltration with damage to lung architecture. Additionally, excessive collagen deposition was observed within lung structure with a mean histological score of (7.38 \pm 0.18 , Fig. 2, A\& B). Administration of irbesartan $(10,20$ and $40 \mathrm{mg} / \mathrm{kg})$ suppressed BLM-induced pulmonary fibrosis and enhanced the histopathological picture of the lung which is associated with a reduction in the mean histopathological score compared to BLM group (P < 0.05, Fig. 2, A\& B). Further, irbesartan ( 20 and $40 \mathrm{mg} / \mathrm{kg}$ ) showed a decrease in the mean fibrosis score compared to irbesartan $(10 \mathrm{mg} / \mathrm{kg}, \mathrm{P}<0.05)$. Irbesartan $(40 \mathrm{mg} / \mathrm{kg})$ decreased mean fibrosis score compared to irbesartan $(20 \mathrm{mg} / \mathrm{kg}, \mathrm{P}<0.05)$. In addition, healthy rats treated with the highest dose of irbesartan $(40 \mathrm{mg} / \mathrm{kg})$ showed mild-moderate inflammation and leukocytes infiltration with a higher fibrosis grade compared to vehicle-group but lower fibrosis grade compared to BLM-group ( $\mathrm{P}<0.05$, Fig. 2, A\& B).
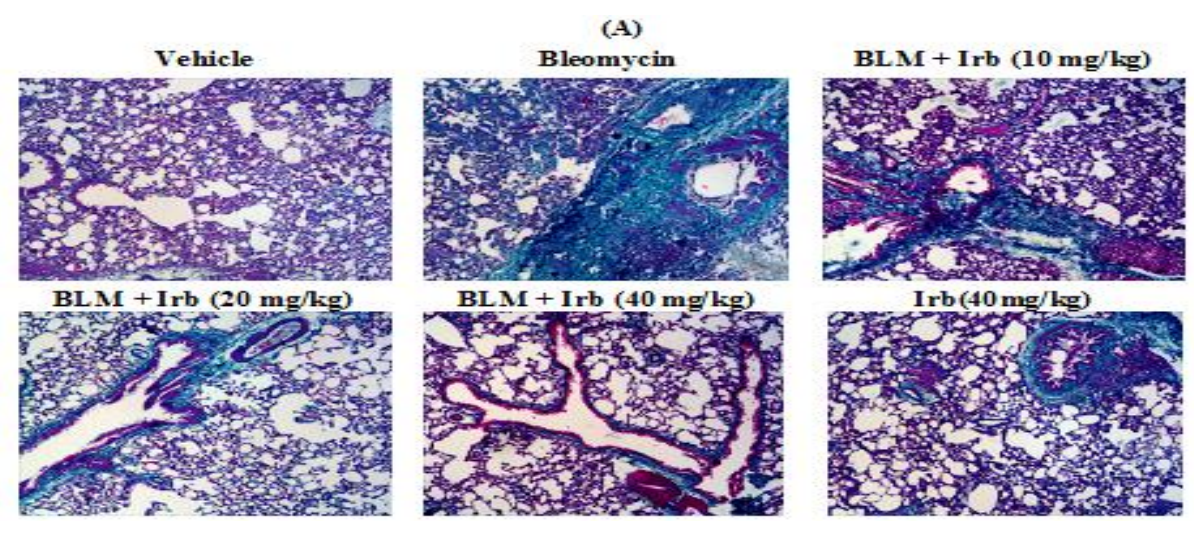

(B)

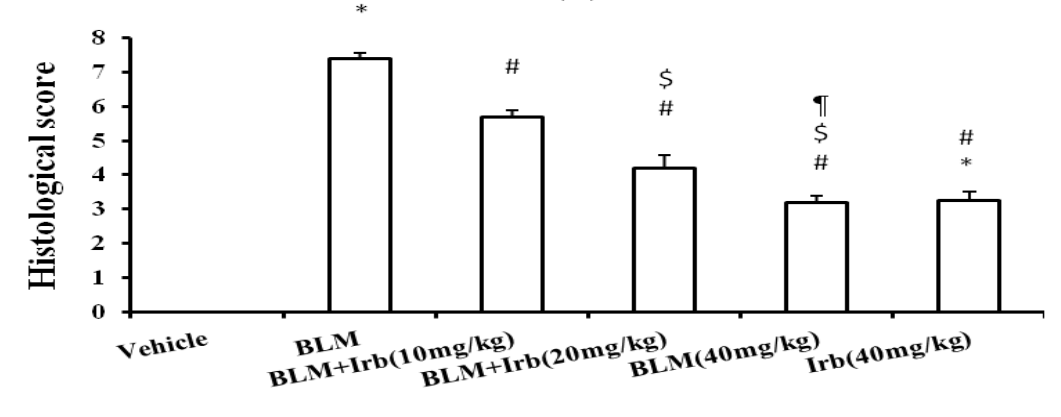


Figure 2: (A) Histopathological picture for lungs of different experimental groups, Masson's trichrome stain $(\mathrm{x} 40)$. (B) The histopathological score of the experimental groups. Values are expressed as mean \pm S.E.M. and analyzed using one-way ANOVA followed by Bonferroni's multiple comparisons test. BLM: bleomycin, Irb: irbesartan. "Compared to vehicle group at $\mathrm{P}<0.05$, ${ }^{\#}$ Compared to BLM group at $\mathrm{P}$ $<0.05,{ }^{\$}$ Compared to irbesartan $(10 \mathrm{mg} / \mathrm{kg})$ group at $\mathrm{P}<0.05,{ }^{\text {đI }}$ Compared to irbesartan $(20 \mathrm{mg} / \mathrm{kg})$ group at $\mathrm{P}$ $<0.05, \mathrm{n}=10$.

\subsection{Effect of irbesartan on immunohistochemical staining for $\mathrm{AT}_{1}, \boldsymbol{\alpha}-\mathrm{SMA}$ or VEGF in lung tissues}

Immunohistochemical staining indicated high immunostaining of $\mathrm{AT}_{1}$ receptors, VEGF and $\alpha$-SMA in the lungs of BLM-treated rats compared to vehicle-treated rats $(\mathrm{P}<0.05$, Fig. 3A, B, C \& D). Treatment with irbesartan $(10,20 \& 40 \mathrm{mg} / \mathrm{kg})$ reduced immunostaining of $\mathrm{AT}_{1}$ receptors compared to BLM group $(\mathrm{P}<0.05$, Fig. 3, A\& D). Treatment with irbesartan $(20$ and $40 \mathrm{mg} / \mathrm{kg})$ reduced immunostaining of $\alpha-\mathrm{SMA}(\mathrm{P}<0.05$, Fig. $3, \mathrm{C} \& \mathrm{D})$ with increasing immunostaining of VEGF compared to BLM and irbesartan $(10 \mathrm{mg} / \mathrm{kg})$ groups $(\mathrm{P}<$ 0.05, Fig. 3, B\& D). Further, treatment of survived rats with irbesartan $(40 \mathrm{mg} / \mathrm{kg})$ decreased immunostaining of $\alpha$-SMA compared to irbesartan $(20 \mathrm{mg} / \mathrm{kg})$. However, healthy rats treated with irbesartan $(40 \mathrm{mg} / \mathrm{kg})$ showed a comparable immunostaining of $\mathrm{AT}_{1}$ receptors and $\alpha$-SMA (Fig. 3A, C\& D) with higher immunostaining of VEGF compared to the vehicle group (P < 0.05, Fig. 3B\& D) but Lower immunostaining of $\mathrm{AT}_{1}$ and $\alpha-\mathrm{SMA}$ compared to BLM-group (P < 0.05, Fig. 3A, C \& D).
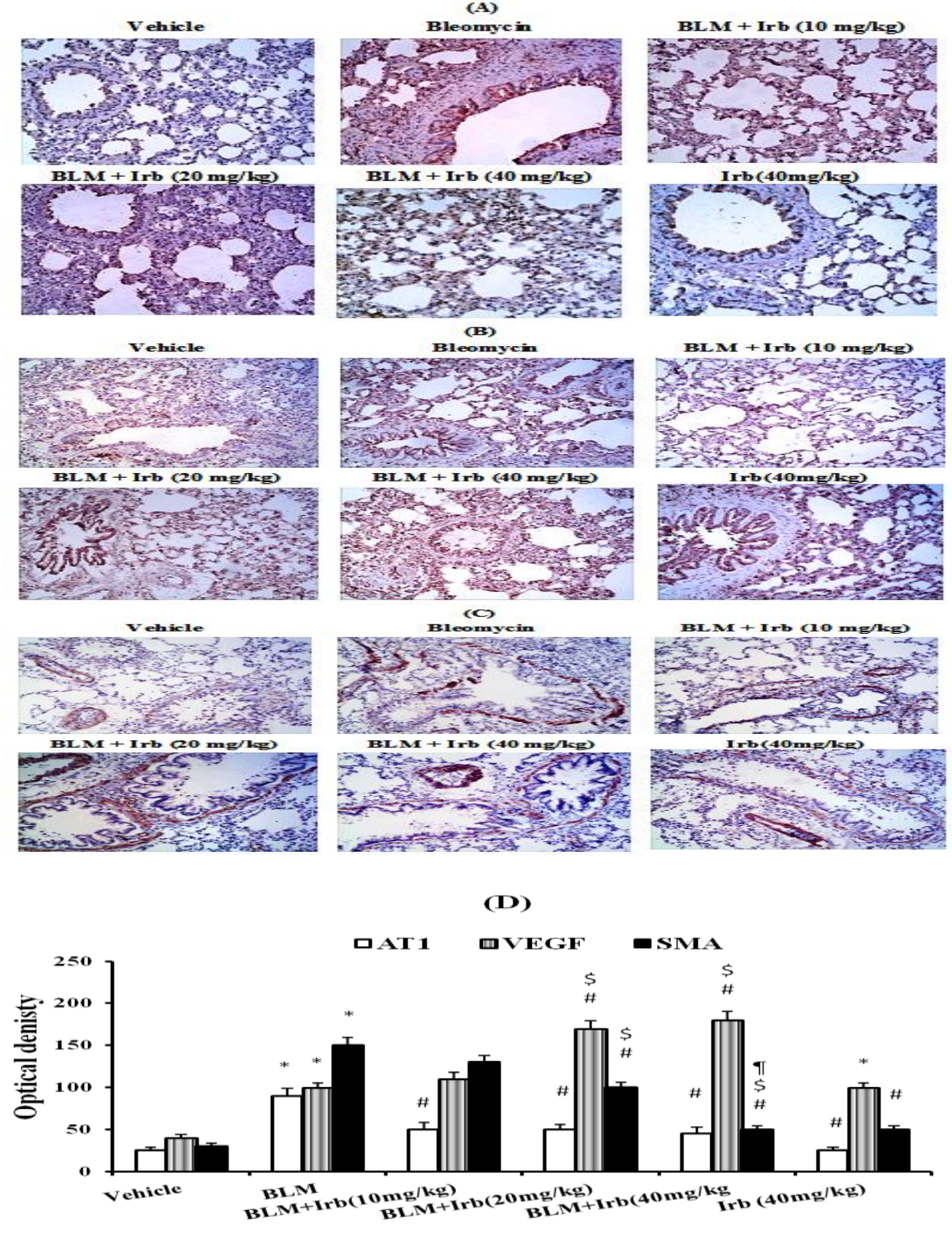
Figure 3: Effect of irbesartan $(10,20$ and $40 \mathrm{mg} / \mathrm{kg})$ on immunohistochemical staining for AT1 (A), VEGF (B) and $\alpha$-SMA $(\mathrm{C})$ in the lung tissues of BLM-induced fibrosis in rats (x 100 magnification). Optical density for $\mathrm{AT}_{1}, \mathrm{VEGF}$ or $\alpha$-SMA positive tissues in the experimental groups (D). Results are expressed as mean \pm S.E.M. and analyzed using one-way ANOVA followed by Bonferroni's multiple comparisons test. BLM: bleomycin, Irb: irbesartan * Compared to vehicle group at $\mathrm{P}<0.05,{ }^{*}$ Compared to BLM group at $\mathrm{P}<0.05,{ }^{\$}$ Compared to irbesartan $(10 \mathrm{mg} / \mathrm{kg})$ group at $\mathrm{P}<0.05,{ }^{\mathrm{I}}$ Compared to irbesartan $(20 \mathrm{mg} / \mathrm{kg})$ group at $\mathrm{P}<0.05, \mathrm{n}=10$.

\subsection{Effect of irbesartan on PAI-1 gene expression}

Injection with BLM resulted in a higher increase in gene expression of PAI-1 in lung tissues compared to vehicle-treated rats $(\mathrm{P}<0.05$, Fig. 4). Treatment with irbesartan $(10,20$ and $40 \mathrm{mg} / \mathrm{kg})$ decreased gene expression of PAI-1 compared to BLM group ( $\mathrm{P}<0.05$, Fig. 4). Further, treatment with irbesartan $(40 \mathrm{mg} / \mathrm{kg})$ showed lower gene expression of PAI-1 in the survived rats compared to irbesartan (10 and $20 \mathrm{mg} / \mathrm{kg}$ ). However, healthy rats treated with irbesartan $(40 \mathrm{mg} / \mathrm{kg})$ showed higher expression of PAI-1 compared to the vehicle group but lower gene expression compared to BLM-group ( $\mathrm{P}<0.05$, Fig. 4).

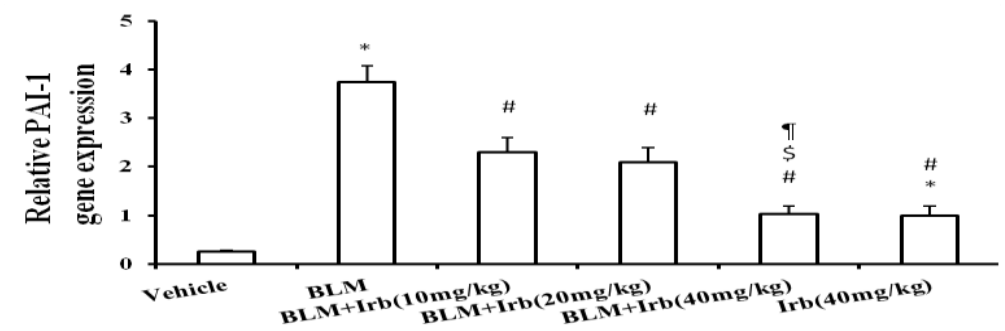

Figure 4: Effect of irbesartan $(10,20$ and $40 \mathrm{mg} / \mathrm{kg})$ on expression of PAI-1 gene in lung tissue of BLM-induced fibrosis in rats. Results are expressed as mean \pm S.E.M. and analyzed using one-way ANOVA followed by Bonferroni's multiple comparisons test. BLM: bleomycin, Irb: irbesartan. *Compared to vehicle group at $\mathrm{P}<0.05,{ }^{\#}$ Compared to bleomycin group at $\mathrm{P}<0.05,{ }^{\$}$ Compared to irbesartan $(10 \mathrm{mg} / \mathrm{kg})$ group at $\mathrm{P}$ $<0.05,{ }^{\text {TI }}$ Compared to irbesartan $(20 \mathrm{mg} / \mathrm{kg})$ group at $\mathrm{P}<0.05, \mathrm{n}=10$.

\section{DISCUSSION}

In the present study, injection of BLM increased collagen deposition and induced histopathological changes in lungs with high degree of fibrosis; this was in agreement with the findings reported previously [17, 18]. BLM-treated rats exhibited higher reductions in their body weights through out the entire course of the experiment with an increase in lung coefficient at the end of the experiment. These results were in consistence with $[14,17]$ Administration of irbesartan $(40 \mathrm{mg} / \mathrm{kg})$ resulted in significant reduction in the marked weight losses and reduced the increase in lung coefficients without reaching those of the control animals.

Immunohistochemical staining of $\mathrm{AT}_{1}$ receptors has been increased in BLM treated rats while treatment with irbesartan $(10,20$ and $40 \mathrm{mg} / \mathrm{kg})$ induced a significant decrease in $\mathrm{AT}_{1}$ receptors compared to BLM group. In agreement, $\mathrm{AT}_{1}$ receptors expression was up regulated in fibrotic heart [19], liver [20], kidney [21], pancreas [22] and lung [23]. Whereas, valsartan reduced the increase in $\mathrm{AT}_{1}$ receptor expression and lung injury in bleomycin-treated rats [24] and irbesartan significantly down-regulated the renal expression of $\mathrm{AT}_{1}$ receptor in 5/6 nephrectomized rats [21].

In the current study, BLM increased mRNA gene expression of PAI-1 in lung tissues. Similarly, immunohistochemical expression of PAI-1 protein in BLM-fibrotic lungs of mice confirmed the role of PAI-1 in the fibrotic phase rather than the acute inflammatory phase [25]. Further, it has been shown that a targeted deletion of the PAI1 gene in mice delayed the development of fibrosis [26], whereas, overexpression of PAI-1 increased deposition of collagen and fibrin and produced more severe lung fibrosis induced by BLM in mice [27].

Irbesartan administration decreased the gene expression of PAI-1 compared to BLM. In consistence with [28], $\mathrm{AT}_{1}$ receptors blockade reduced mRNA expression of PAI-1 which was induced after continuous intrajugular infusion of angiotensin-II in the aorta and heart of hypertensive rats. Further, olmesartan was reported to inhibit hepatic fibrosis and expression of fibrogenic genes including PAI-1 in rat model of non-alcoholic steatohepatitis [29]. Pretreatment with Losartan reduced Lipopolysaccharide-induced PAI-1 levels in mice lungs [30]. Importantly, clinical data demonstrated a reduction in plasma levels of PAI-1 which was observed after 4 weeks of irbesartan therapy in patients with metabolic syndrome [31]. Additionally, the progression of pulmonary fibrosis induced by BLM in rats was attenuated by administration of PAI-1 small interfering RNA [32]. Therefore, PAI-1 is an important factor attributed in lung fibrosis.

Regarding VEGF, BLM-treated rats showed high serum level and immunohistochemical staining of VEGF in lung tissues compared to vehicle group. In agreement, VEGF increased in lung tissues in BLM-treated rodent, peaked at early phase after BLM administration and decreased up to the end of experiment, in fibrotic phase [33, 34].

Additionally, treatment with irbesartan increased serum VEGF level and immunohistochemical staining of VEGF in lung tissues compared to BLM group. In consistence with35, blockade of $\mathrm{AT}_{1}$ receptor by losartan reversed the decrease of microvessel density in rats hearts after myocardial infarction. Inhibition of angiotensin converting enzyme by quinaprilat induced angiogenesis in the rabbit model of hindlimb ischemia [36]. In addition, Losartan induced angiogenesis in mice 
through activation of $\mathrm{AT}_{2}$ receptor in alginate implant angiogenesis model while an impaired induction of angiogenesis was shown in $\mathrm{AT}_{2}$ receptor knockout mice [37].

Further, study of Farkas et al. [38] demonstrated the reduced VEGF levels and microvasculaization loss with increasing degrees of fibrosis in fibroblastic foci and fibrotic interstitium in rats with experimentally-induced lung fibrosis. The increased vascular density in the least fibrotic areas contributed to the regeneration of alveolar septa damaged by the fibrotic process [39]. Therefore, the protective effect of irbesartan in fibrotic lung may be attributed, in part, to upregulation of VEGF.

In the present study, serum TNF- $\alpha$ level did not differ significantly among all the study groups. TNF- $\alpha$ contributed to the pathophysiology of interstitial lung disease through induction of TGF- $\beta_{1}$ expression [40]. The expression of TNF- $\alpha$ rises in the lung at early phase while the level of TNF- $\alpha$ was below the limit of detection at the fibrotic phase in mice with BLM-induced lung fibrosis [41] or decreased gradually on day 14 and 28 in fibrotic lung of BLM-treated rats [14]. Therefore, the results of the current study may suggest that the increase in the experimental TNF- $\alpha$ did not continue until the end of the experiment.

Our results revealed that administration of bleomycin was accompanied by high levels of TGF- $\beta_{1}$ in the serum. This was in consistence with various studies that indicated an increase of TGF- $\beta_{1}$ level in the serum [42], bronchoalveolar lavage fluid [23] of rats with BLM-fibrotic lungs. In addition to lung biopsies obtained from patients with idiopathic pulmonary fibrosis43 and mice with BLM-induced fibrotic lungs [44]. Thereby, increased expression of TGF- $\beta_{1}$ is believed to be a critical mediator during initiation and progression of fibrosis.

Additionally, the present results found that treatment with irbesartan decreased the serum TGF- $\beta_{1}$ level compared to BLM-treated group. Similarly, $\mathrm{AT}_{1}$ receptor blockers suppressed TGF- $\beta_{1}$ expression in the lung42, kidney 45 , pancreas 46 and liver [29]. Further, administration of irbesartan reduced TGF- $\beta_{1}$ level in bronchoalveolar lavage fluid in mice with fibrotic lungs [12] and suppressed up-regulation of renal expression of TGF- $\beta_{1}$ in 5/6 nephrectomized rats [21]. Valsartan attenuated the progression of hepatic fibrosis in type 2 diabetic rats via reducing TGF- $\beta_{1}$ [47].

Bleomycin injection in the present study resulted in an increase of $\alpha$-SMA immunostaining in lung tissues while treatment with irbesartan reduced this increase. In agreement, the presence of $\alpha$-SMA-expressing myofibroblasts in the affected tissue is typical for all fibrotic diseases [48]. Further, irbesartan reduced $\alpha$-SMA expression in fibrotic skin of mice [13] and Valsartan suppressed the expression of $\alpha$-SMA in fibrotic liver of rats [47]. Administration of Irbesartan $(40 \mathrm{mg} / \mathrm{kg})$ to healthy rats resulted in increasing serum level of TGF- $\beta_{1}$ and gene expression of PAI- 1 in lung tissues and this will need further studies to be explained.

\section{CONCLUSIONS}

This work demonstrated that the ameliorating effect of irbesartan against pulmonary fibrosis induced by bleomycin in rats involves induction of angiogenesis, reduction of pulmonary expression of PAI-1 and modulation of fibrotic mediators. Consequently, the present results support the harmful role of $\mathrm{AT}_{1}$ receptors in mediating the effects of angiotensin-II in bleomycin-induced pulmonary injury and fibrosis in rats.

\section{ACKNOWLEDGMENTS}

The authors wish to acknowledge the generous gift of irbesartan from Medical Union Pharmaceuticals (Ismailia, Egypt).

\section{REFERENCES}

[1] American Thoracic Society / European Respiratory Society. International Multidisciplinary Consensus Classification of the Idiopathic Interstitial Pneumonias, Am J Respir Crit Care Med, 165, 2002, 277-304.

[2] American Thoracic Society. Idiopathic Pulmonary Fibrosis: Diagnosis and Treatment International Consensus Statement, $A m J$ Respir Crit Care Med, 161, 2000, 646-664.

[3] H Umezawa, K. Meaeda, T. Takeuchi, and Y. Okami, New antibiotics, bleomycin A and B, J Antibiot (Tokyo), 19(5), 1966, 200205.

[4] F Chua, J. Gauldie, and G. Laurent, Pulmonary fibrosis: searching for model answers. Am J Respir Cell Mol Biol, 33(1), 2005, 913.

[5] M de Gasparo, K. Catt, T. Inagami, J. Wright, and T. Unger, International Union of Pharmacology XXIII. The angiotensin II receptors, Pharmacol Rev, 52(3), 2000, 415- 472.

[6] X Gao, X. He, B. Luo, L. Peng, J. Lin, and Z. Zuo, Angiotensin II increases collagen I expression via transforming growth factorbeta1 and extracellular signal-regulated kinase in cardiac fibroblasts, Eur J Pharmacol, 606, 2009, 115-120.

[7] Y Kang, Y. Park, B. Kim, S. Han, Y. Jee, K. Han, M. Lee, H. Song, D. Cha, S. Kang, and D. Han, Angiotensin II stimulates the synthesis of vascular endothelial growth factor through the p38 mitogen activated protein kinase pathway in cultured mouse podocytes, J Mol Endocrinol, 36(2), 2006, 377-388.

[8] R Liu, Oxidative stress, plasminogen activator inhibitor 1, and lung fibrosis, Antioxid Redox Signal 10(2), 2008, 303-319.

[9] E Kruithof, Plasminogen activator inhibitors: a review, Enzyme, 40, 2008, 113-121.

[10] W Baricos, S. Cortez, S. El-Dahr, and H. Schnaper, ECM degradation by cultured human mesangial cells is mediated by a PA/plasmin/MMP-2 cascade, Kidney Int, 47(4), 1995, 1039-1047.

[11] K Croom, and G. Plosker, Irbesartan: a review of its use in hypertension and diabetic nephropathy, Drugs, 68(11), 2008, 15431569 .

[12] J Tanaka, S. Tajima, K. Asakawa, T. Sakagami, H. Moriyama, T. Takada, E. Suzuki, and I. Narita, Preventive effect of irbesartan on bleomycin-induced lung injury in mice. Respir Invest, 2013 (In press).

[13] W Marut, N. Kavian, A. Servettaz, T. Hua-Huy, C. Nicco, C. Chéreau, B. Weill, A. Dinh-Xuan, F. Batteux, Angiotensin II receptor blockade ameliorates systemic fibrosis in the mouse. Arthritis Rheum 2013. (In press) 
[14] C Zhou, W. Han, P. Zhang, M. Cai, D. Wei, and C. Zhang, Lycopene from tomatoes partially alleviates the bleomycin-induced experimental pulmonary fibrosis in rats, Nutr Res, 28(2), 2008, 122-130.

[15] T Ashcroft, J. Simpson, and V. Timbrell, Simple method of estimating severity of pulmonary fibrosis on a numerical scale, J Clin Pathol, 41(4), 1988, 467-470.

[16] G Wagenaar, S. ter Horst, M. van Gastelen, L. Leijser, T. Mauad, P. van der Velden, E. de Heer, P. Hiemstra, B. Poorthuis, and F. Walther, Gene expression profile and histopathology of experimental bronchopulmonary dysplasia induced by prolonged oxidative stress, Free Radic Biol Med, 36(6), 2003,782-801.

[17] A El-Medany, H. Hagara, M. Moursib, R. At Muhammed, F. El-Rakhawyc, and G. El-Medany, Attenuation of bleomycin-induced lung fibrosis in rats by mesna, Eur J Pharmacol, 509(1), 2005, 61-70.

[18] G Li, S. Pi, Z. Xu, C. Liu, X. Wang, B. Liao, and X. Yin, Signal transducer and activator of transcription 6 expression in bleomycin-induced lung fibrosis in rats, J Chin Clin Med, 3(9), 2008, 481-487.

[19] V Robert, C. Heymes, J. Silvestre, A. Sabri, B. Swynghedauw, and C. Delcayre, Angiotensin AT1 receptor subtype as a cardiac target of aldosterone: role in aldosterone-salt-induced fibrosis, Hypertension, 33(4), 1999, 981-986.

[20] X Li, Y. Meng, X. Yang, Z. Zhang, P. Wu, and J. Zou, Perindopril attenuates the progression of CCl4-inducing rat hepatic fibrosis, Zhonghua Gan Zang Bing Za Zhi, 12(1), 2004, 32-34.

[21] G Zhao, H. Zhao, L. Tu, X. Xu, C. Zheng, M. Jiang, P. Wang, and D. Wang, Effects and mechanism of irbesartan on tubulointerstitial fibrosis in 5/6 nephrectomized rats, J Huazhong Univ Sci Technolog Med Sci, 30(1), 2010, 48-54.

[22] Y Nagashio, H. Asaumi, S. Watanabe, Y. Nomiyama, M. Taguchi, M. Tashiro, T. Sugaya, and M. Otsuki, Angiotensin II type 1 receptor interaction is an important regulator for the development of pancreatic fibrosis in mice, Am J Physiol Gastrointest Liver Physiol, 287(1), 2004, G170-G177.

[23] M Otsuka, H. Takahashi, M. Shiratori, H. Chiba, and S. Abe, Reduction of bleomycin induced lung fibrosis by candesartan cilexetil, an angiotensin II type 1 receptor antagonist, Thorax, 59(1), 2004, 31-8.

[24] F Chen, L. Gong, L. Zhang, H. Wang, X. Qi, X. Wu, Y. Xiao, Y. Cai, L. Liu, X. Li, and J. Ren, Early lung injury contributes to lung fibrosis via AT1 receptor in rats, Acta Pharmacol Sin, 28(2), 2007, 227-237.

[25] M Ueno, T. Maeno, M. Nomura, K. Aoyagi-Ikeda, H. Matsui, K. Hara, T. Tanaka, T. Iso, T. Suga, and M. Kurabayashi, Hypoxiainducible factor-1 $\alpha$ mediates TGF- $\beta$-induced PAI-1 production in alveolar macrophages in pulmonary fibrosis, Am J Physiol Lung Cell Mol Physiol, 300(5), 2011, L740-L752.

[26] S Chuang-Tsai, T. Sisson, N. Hattori, C. Tsai, N. Subbotina, K. Hanson, and R. Simon, Reduction in fibrotic tissue formation in mice genetically deficient in plasminogen activator inhibitor-1, Am J Pathol, 163(2), 2003, 445-452.

[27] D Eitzman, R. McCoy, X. Zheng, W. Fay, T. Shen, D. Ginsburg, and R. Simon, Bleomycin-induced pulmonary fibrosis in transgenic mice that either lack or over express the murine plasminogen activator inhibitor-1gene, J Clin Invest, 97(1), 1996, 232237.

[28] H Chen, J. Bouchie, A. Perez, A. Clermont, S. Izumo, J. Hampe, and E. Feener, Role of the angiotensin AT1 receptor in rat aortic and cardiac PAI-1 gene expression, Arterioscler Thromb Vasc Biol, 20(10), 2000, 2297-2302.

[29] S Kurit, T. Takamura, T. Ota, N. Matsuzawa-Nagata, Y. Kita, M. Uno, S. Nabemoto, K. Ishikura, H. Misu, H. Ando, Y. Zen, Y. Nakanuma, and S. Kaneko, Olmesartan ameliorates a dietary rat model of non-alcoholic steatohepatitis through its pleiotropic effects, Eur J Pharmacol, 588, 2008, 316-324.

[30] P Arndt, S. Young, K. Poch, J. Nick, S. Falk, R. Schrier, and G. Worthen, Systemic inhibition of the angiotensin-converting enzyme limitlipopolysaccharide-induced lung neutrophil recruitment through both bradykinin and angiotensin II-regulated pathways, J Immunol, 177(10), 2006, 7233-7241.

[31] S Sola, M. Mir, F. Cheema, N. Khan-Merchant, R. Menon, S. Parthasarathy, and B. Khan, Irbesartan and lipoic acid improve endothelial function and reduce markers of inflammation in the metabolic syndrome: results of the irbesartan and lipoic acid in endothelial dysfunction (ISLAND) Study, Circulation, 111(3), 2005, 343-348.

[32] Y Zhang, W. Li, W. Wang, J. Liu, S. Song, L. Bai, Y. Hu, Y. Yuan, and M. Zhang, siRNA against plasminogen activator inhibitor-1 ameliorates bleomycin-induced lung fibrosis in rats, Acta Pharmacol Sin, 33(7), 2012, 897-908.

[33] N Hamada, K. Kuwano, M. Yamada, N. Hagimoto, K. Hiasa, K. Egashira, N. Nakashima, T. Maeyama, M. Yoshimi, and Y. Nakanishi, Anti-vascular endothelial growth factor gene therapy attenuates lung injury and fibrosis in mice, J Immunol, 175(2), $2005,1224-1231$.

[34] S Lee, A. Jang, Y. Kim, J. Cha, T. Kim, S. Jung, S. Park, Y. Lee, J. Won, Y. Kim, and C. Park, Modulation of cytokine and nitric oxide by mesenchymal stem cell transfer in lung injury/fibrosis, Respir Res, 11, 2010, 16-30.

[35] R de Boer, Y. Pinto, A. Suurmeijer, S. Pokharel, E. Scholtens, M. Humler, J. Saavedra, F. Boomsma, W. van Gilst, and D. van Veldhuisen, Increased expression of cardiac angiotensin II type 1 (AT1) receptors decreases myocardial microvessel density after experimental myocardial infarction, Cardiovasc Res, 57(2), 2003, 434-442.

[36] J Fabre, A. Rivard, M. Magner, M. Silver, and J. Isner, Tissue inhibition of angiotensin-converting enzyme activity stimulates angiogenesis in vivo, Circulation, 99, 1999, 3043-3049.

[37] T Walther, A. Menrad, H. Orzechowski, G. Siemeister, M. Paul, and M. Schirner, Differential regulation of in vivo angiogenesis by angiotensin II receptors, FASEB J, 17(14), 2003, 2061-2067.

[38] L Farkas, D. Farkas, K. Ask, A. Möller, J. Gauldie, P. Margetts, M. Inman, and M. Kolb, VEGF ameliorates pulmonary hypertension through inhibition of endothelial apoptosis in experimental lung fibrosis in rats, J Clin Invest, 119(5), 2009, 12981311.

[39] M Ebina, M. Shimizukawa, N. Shibata, Y. Kimura, T. Suzuki, M. Endo, H. Sasano, T. Kondo, and T. Nukiwa, Heterogeneous increase in CD34- positive alveolar capillaries in idiopathic pulmonary fibrosis, Am J Respir Crit Care Med, 169(11), 2004, 12031208.

[40] D Sullivan, M. Ferris, D. Pociask, and A. Brody, The latent form of TGF beta(1) is induced by TNF-alpha through an ERK specific pathway and is activated by asbestos-derived reactive oxygen species in vitro and in vivo, J Immunotoxicol, 5(2), 2008, $145-149$.

[41] Y Waseda, M. Yasui, Y. Nishizawa, K. Inuzuka, H. Takato, Y. Ichikawa, A. Tagami, A. Fujimura, and S. Nakao, Angiotensin II type 2 receptor antagonist reduces bleomycin-induced pulmonary fibrosis in mice, Respir Res, 9, 2008, 43-51.

[42] H Yao, J. Zhu, M. Zhao, and Y. Lu, Losartan attenuates bleomycin- induced pulmonary fibrosis in rats, Respiration, 73(2), 2006, 236-242.

[43] T Broekelmann, A. Limper, T. Colby, and J. McDonald, Transforming growth factor beta 1 is present at sites of extracellular matrix gene expression in human pulmonary fibrosis, Proc Natl Acad Sci, 88(15), 1991, 6642-6646. 
[44] C Lee, R. Homer, Z. Zhu, S. Lanone, X. Wang, V. Koteliansky, J. Shipley, P. Gotwals, P. Noble, Q. Chen, R. Senior, and J. Elias, Interleukin-13 induces tissue fibrosis by selectively stimulating and activating transforming growth factor beta $1, J$ Exp Med, 194(6), 2001, 809-821

[45] J Boffa, Y. Lu, S. Placier, A. Stefanski, J. Dussaule, and C. Chatziantoniou, Regression of renal vascular and glomerular fibrosis role of angiotensin II receptor antagonism and matrix metalloproteinases, J Am Soc Nephrol, 14(5), 2003, 1132-1144.

[46] T Yamada, A. Kuno, K. Masuda, K. Ogawa, M. Sogawa, S. Nakamura, T. Ando, H. Sano, T. Nakazawa, H. Ohara, T. Nomura, T. Joh, and M. Itoh, Candesartan, an angiotensin II receptor antagonist, suppresses pancreatic inflammation and fibrosis in rats, J Pharmacol Exp Ther, 307(1), 2003, 17-23.

[47] G Qiang, L. Zhang, X. Yang, Q. Xuan, L. Shi, H. Zhang, B. Chen, X. Li, M. Zu, D. Zhou, J. Guo, H. Yang, and G. Du, Effect of valsartan on the pathological progression of hepatic fibrosis in rats with type 2 diabetes, Eur J Pharmacol, 685, 2012, 156-164.

[48] T Kisseleva, and D. Brenner. Mechanisms of fibrogenesis, Exp Biol Med (Maywood), 233(2), 2008, 109-122. 